\title{
水稻の鉄, マンガン,アエンおよび銅含量と
}

\section{葉イモチ病抵抗性との関係*}

鑇、田、悦男

(東京大学農学部)

筆者は, 年来の実験観察によつて, 水稻を含む数種の作物の生育に要する $\mathrm{Fe}, \mathrm{Mn}, \mathrm{Zn}, \mathrm{Cu}$ の量は, D.I. ArNoN ('38) の 4A-Solution の 1/50 30 倍の濃度の限界内では, 各々の元素の絶対量よりも 4 元素間の量的比 率の重要なことを, 培養液に加える各元素の量, それらが植物体中の含量, 植物体の示ず Pathological symptom 和よび生育程度の指標としての 乾物重, 或いは生体重・展開葉数・分けつ数・分枝数拉よび葉面積の 4 者 の比較考察によつて結論した。しかし，その機構については培養液から元素を吸収する面においては，Fe : $\mathrm{Mn}$, $\mathrm{Fe}: \mathrm{Za}, \mathrm{Fe}: \mathrm{Cu}, \mathrm{Mn}: \mathrm{Za}, \mathrm{Mn}: \mathrm{Cu}$ 閒の抬㧤現象の存在によつて説明することが出来るが, 吸収後の生体内 に括ける生理的平衡状態の解眀は目下検討中である.

この現象を作物の生育と，その作物の 4 元素合量という点から見れば，正常な生育条件で人為的に或る程度 Fe. Mn. Zn. Cu 含量を随意飞支配することが出来ることを示するのである.

この方法を用いて，水稲数品橿を実験材料として，4元素合量と葉イモチ抵抗性の関你を観察し，さらに，品 種間差異・培養液の N源の差およびそれ等の絶体量の差・Si 供給量との関係を検討した。

その結果を要約すると次の如くで岁る。

1）水榣無芒愛国を5月 21 日泟砂に播種し，6月 17 日に 4 元素含量の異る HOAGIAND 及 ARNON の培善 液に移し，展開葉数 8 枚の 8 月 8 日にイモチ菌を常法に彷つて接種した。 その結果によると 4 元素含量の增加に 伴つて葉イモ千病抵抗性は顕著に高まつている (表). また，病斑数合計は 4 元素含量の增加に伴つて墭小して いるが，イモチ菌の植物体侵入笝所が最少限度として䙓点型病斑を形成するという証明のない現在においては， この現像から・侵入抵抗性も高るると推論することは出来ない。

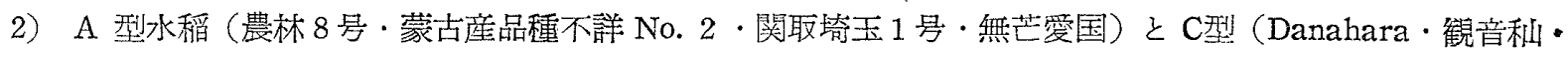
Tadekan）を供試材料として，本現象に刘する品種間差異を見た。その結果，A 型品種では 1）と同一の結果 が笂められ，C型に属するものでは全く認められなかつた（战績省略）。この事実から，A型とC型のイモチ病 抵 抗性は異つた機梼によるものと推定される(型の分類は松尾氏の方法に從う)

4 元素供給量と葉イモチ病抵抗性との関係

\begin{tabular}{|c|c|c|c|c|c|c|c|c|c|c|c|c|c|c|c|c|}
\hline \multirow[b]{2}{*}{ 区 } & \multirow[b]{2}{*}{ 名 } & \multicolumn{4}{|c|}{ 培湌液 の組 成 } & \multicolumn{3}{|c|}{ 接種時の生育状態 } & \multicolumn{4}{|c|}{$\begin{array}{l}\text { 接種後 } 1 \text { 日目の } 1 \\
\text { 個体当 引病斑数 }\end{array}$} & \multicolumn{4}{|c|}{$\begin{array}{c}\text { 植物体の } 4 \text { 元素含量 } \\
(\mathrm{p} . \mathrm{p} . \mathrm{m}) \\
\end{array}$} \\
\hline & & $\mathrm{Fe}$ & $\mathrm{Mn}$ & $\mathrm{Zn}_{\mathrm{n}}$ & $\mathrm{Cu}$ & $\begin{array}{l}\text { 草丈 } \\
(\mathrm{cm})\end{array}$ & $\begin{array}{l}\text { 屡開 } \\
\text { 葉数 }\end{array}$ & 徵候 & $\begin{array}{l}\text { 紡鍾 } \\
\text { 型 }\end{array}$ & $\begin{array}{l}\text { 慢性 } \\
\text { 型 }\end{array}$ & 褐点 & 合計 & $\mathrm{Fe}$ & $\mathrm{Mn}^{\mathrm{M}}$ & $\mathrm{Zn}$ & $\mathrm{cu}$ \\
\hline Al1 & 0 & & Do & 0 & 0 & & 7 & & 9.0 & 14.7 & 87.0 & & Ju & 30 & - & 22 \\
\hline "l & $1 / 50$ & 0.03 & 0.01 & 0.001 & 0.0004 & 50.0 & 8 & 正 常 & 17.0 & 31.0 & 50.7 & 98.7 & 120 & 42 & 43 & 28 \\
\hline 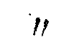 & $1 / 10$ & 0.15 & 0.05 & .005 & 0.002 & 51 & $" \prime$ & $" \prime$ & 14.2 & 24.2 & 44.0 & 82.1 & 170 & 62 & 52 & 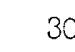 \\
\hline "I & 1 & 1.50 & 0.50 & .050 & 0 & 49.2 & " & " & 7.5 & 12.0 & 16.2 & 34.9 & 180 & 150 & 110 & 49 \\
\hline " & $10 \mathrm{~T}$ & 5.00 & 5.00 & 0.500 & 0.200 & 50.5 & $" \prime$ & " & 0.5 & 1.0 & 7.2 & 11.7 & 420 & 420 & 213 & 99 \\
\hline " & $20 \mathrm{~T}$ & .00 & 10.00 & 1.000 & 0.4000 & 51.0 & " & "I & 0.2 & 1.2 & 5.0 & 6.4 & 570 & 520 & 350 & 105 \\
\hline
\end{tabular}

3）次に本現象と供給 $\mathrm{N}$ 源の形態との関係を見，すなわち， $\mathrm{N}$ 源とし $\mathrm{NO}_{3} \cdot \mathrm{NH}_{4}$ の 2 つを用い，その各々に 4 元素含量の異る区を設けて無芒愛国を栽培して, 病斑数, 全 $\mathrm{N}$ 含量・4 元素含量を比較した結果, 水稲の $\mathrm{Fe}$ $\cdot \mathrm{Mn} \cdot \mathrm{Zn} \cdot \mathrm{Cu}$ 含量はN源の形態とは無関係に各元素の供給量と比例的な関係にあつた（成績省略）。

* 昭和 29 年 4 月 5 日 第 103 回講演会に於て発表

日本作物学会紀事 第 23 巻第 4 号 （昭和 30 年 7 月） 
$\mathrm{NH}_{4}$ を $\mathrm{N}$ 源として $30 \mathrm{mg} / \mathrm{L} \sim 90 \mathrm{mg} / \mathrm{L}$ の各種の濃度とし，さらに，その各々に 1/50〜20 倍の区を設忷， $\mathrm{N}$ 含量と 4 元素含量を比較した結果, $\mathrm{N}$ 含量の高い条件内でも 4 元素含量の增加によつて抵抗性の高まるを認 わた。 (成績省略).

5） Si 合量との関係を見るために, Si 100mg/L-200mg/L の各濃度に，さらに，先の各々に 1 20 倍の区 を設け, $\mathrm{SiO}_{2} \cdot \mathrm{CaO} \cdot \mathrm{MgO} \cdot \mathrm{Fe} \cdot \mathrm{Mn} \cdot \mathrm{Cu}$ 含量と羅病性を検定した結果, $\mathrm{SiO}_{2}$ 含量堌加によるるのと元素含量 堌加による抵抗性は全く異るるのであることを認めた（成績省略）。

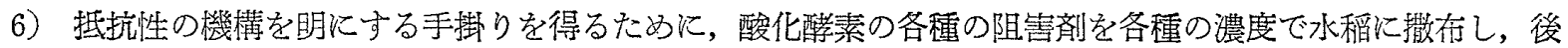

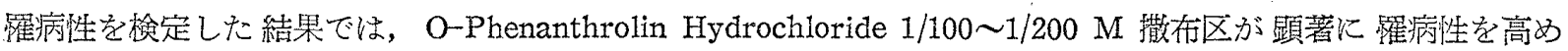
た（成績省略）.

なお，本实験は野口教授の御指導のもとに行つたものである，こつに御礼审しあげる次第である。

\section{Relationship between Iron-, Manganese-, Zinc- and Copper-Contents in Rice Plant and Its Resistance to the Wilting \\ (Piricularia Oriyzae). (An Epitonic Report) \\ Etuo Kamata, \\ (Faculty of Agriculture, University of Tokyo) \\ Résumé}

The variation in the iron, manganese, zinc and copper levels in the leaf of rice plant of the susceptible variety was found definitely related to the intensity of susceptibility of the plant to wilting disease.

In general, high concentration of those elements strengthen the plant's resistance: the phenomenon was proved not to be dependent on the nitrogen, magnesium, calcium or silica levels in the plant soody.

[Continued from the page 280]

to coincide with that of natural starch synthesis, except in the embryo of an early stage of germination. Therefore, phosphorylase seems to be closely connected with the synthesis of starch.

III. Histochemical demonstration of phosphorylase in the cells with high amylase activity.

No starch was found in the natural wheat leaf. However, when the amylase activity was inhibited artificially with mercuric chloride and $\mathrm{pH}$ was made suitable for phosphorylase activity, starch was formed by the action of phosphorylase in the tissue of the wheat leaf. Therefore, the reason why starch is not synthetized in the natural leaves of wheat seemed to be due to the high amylase activity and inadequate value of $\mathrm{pH}$ for phosphorylase activity. In order to make histochemical demonstration of phosphorylase in the cell of high amylase activiy, mercuric chloride must be added in suitable concentration for inhibition of amylase activity. The optimum concentration of mercuric chloride was found to be $\mathrm{M} / 100,000$ in the leaves of wheat (var. Saitama No. 27 and Norin No. 50). 